\title{
Disease as enemy: Journalistic discourse analysis about dengue fever
}

\author{
Luiz Marcelo Robalinho Ferraz ${ }^{1}$, Isaltina Maria de Azevedo Mello Gomes ${ }^{2}$ \\ ${ }^{1}$ Programa de Pós-graduação em Informação e Comunicação em Saúde, Fundação Oswaldo Cruz (Fiocruz), Rio de Janeiro, Brazil \\ ${ }^{2}$ Departamento de Comunicação Social, Universidade Federal de Pernambuco (UFPE), Recife, Brazil
}

Email address:

marcelorobalinho@yahoo.com.br (L. M. R. Ferraz), isaltina@gmail.com (I. M. de A. M. Gomes)

\section{To cite this article:}

Luiz Marcelo Robalinho Ferraz, Isaltina Maria de Azevedo Mello Gomes. Disease as Enemy: Journalistic Discourse Analysis about Dengue Fever. International Journal of Literature and Arts. Special Issue: Discourses of Militarization and Identity: Literature of Conflict. Vol. 2, No. 6-1, 2014, pp. 23-29. doi: 10.11648/j.ijla.s.2014020601.14

\begin{abstract}
Dengue fever is one of the current concerns of Brazilian public health. It emerged and became well known in Brazil in the 1980s, when successive outbreaks were registered in several cities. The purpose of this article is to evaluate the media treatment given to dengue fever, a disease that is increasingly affecting Brazilian people. Starting from the explosive outbreak recorded in 2002, we seek to understand the discourse construction about the disease, by evaluating the discursive strategies used in 2002, 2004, 2006 and 2008. We selected 291 news published in Jornal do Commercio, a daily newspaper of Recife (State of Pernambuco), about the situation of dengue and linked them to the notifications of the disease recorded by the Health Department of Pernambuco. The increase of cases and fatalities has a strong journalistic appeal, requiring an almost daily narrative of the events related to the disease's threat. The notion of outbreak built over the centuries is essential to analyze the effects of signification produced nowadays about infectious diseases as dengue fever. Moreover the discourse of militarization observed in the media through war metaphors is commonly used to emphasize the fear and the necessity of adoption of preventive practices.
\end{abstract}

Keywords: Dengue Fever, Journalistic Discourse, Newsworthiness, Outbreaks, War Metaphors

\section{Introduction}

Dengue is one of the main problems of public health worldwide. Currently it affects almost all continents, except Europe, infecting from 50 to 100 million people annually in more than 100 countries, leading to the hospitalization of 550 000 patients and the death of about 20000 individuals (World Health Organization, 2014). In Brazil, this disease has constant epidemic cycles, especially with reported cases and deaths, including children.

The first references of the disease date back to 1846 in cities of São Paulo, Rio de Janeiro and Salvador. Although dengue was present since the colonial period, in fact it has emerged and has become known in the country in the second half of the 1980 s of the twentieth century, after the reintroduction of Aedes aegypti (carrier of the disease).

The explosive outbreak in 2002 - caused by the introduction of third serotype (DENV-3) in Brazil and that involves explosive characteristic "in a short time, virtually all of those affected" and have rapid progression of cases as a criterion differentiating (Rouquayrol and Almeida Filho, 2003, p. 142) - was a significant achievement for public health in the state of Pernambuco. There were 116,245 notifications and 96,470 confirmed cases of classic dengue and 340 of the hemorrhagic type, and 20 deaths, being decisive for the media to disseminate widely the subject.

In this article, we try to evaluate the treatment given to dengue by the media in the newspaper Jornal do Commercio, of the state of Pernambuco. Taking 2002 as a starting point, we conduct an analysis of the discursive strategies used in 2002, 2004, 2006 and 2008 in the newspaper discourse. This newspaper was chosen as material study due to its position of being one of the three most important newspapers in Pernambuco and due to it's large circulation in the state. It has an average paid circulation of 31,847 copies sold on Tuesday (day of its lower circulation), reaching 65,028 copies on Sunday (day of its largest circulation) ${ }^{1}$. We focus

\footnotetext{
${ }^{1}$ Information regarding in May 2009 provided by the Institute of Movement Checker-IVC (www.ivc.org.br), a nonprofit organization formed and direct by
} 
the analysis on news and notes published during these four years, totalizing 291 written texts.

\section{The Memory on Dengue Discourse}

Considering the press as a cultural object and a locus of social memory, we argue that the construction of the journalistic discourse about dengue fever was based on the present and the past of various infectious diseases. In news production about dengue, memory plays an important role by invoking prebuilt elements, or existing traits in other discourses. Based on the idea of assumption, the term pre-built "means an earlier, external and independent construction opposed to what is built in the enunciation", referring to what "everyone knows" and, at the same time, to what "each one can see" in a given situation (Courtine, 2009, p. 74-5).

To Discourse Analysis (DA), discourse is seen as a practical structure of language that unites present and memory at the same time. Based on previously established senses(memory), the discourse is constituted from new developments, which melts regularizations existence, giving rise to a new system through a game of power that aims to keep the already-produced and, in the opposite direction, modify the existing senses, according to Pêcheux (2007).

Reflections on discourse and discursive memory led to the concept of interdiscourse, recognizing that discourses are not isolated, but linked to each other. Charaudeau and Maingueneau determine two senses to interdiscourse: a more restrictive one, referring to a discursive space, "a set of discourses (of the same discursive field or different fields) that maintain relationships of mutual boundaries with each other", and a more vast one, as "a set of discursive units (previous discourses that belong to the same genre of contemporary discourses of other genres, etc..) with which a particular discourse comes into implicit or explicit relationship" (Charaudeau and Maingueneau, 2008, p. 286, authors' italics).

Although the diseases have distinct characteristics, the feelings that surround each one - sickness, fear, evil, danger, death and pestilence - mobilize networks of shared memory on diseases in general (Ferraz, 2010, author italics). By association process, new senses are being produced based on existing ones through an interdiscursive process that establishes points of contact with other fields, especially the military field, as war discourse observed in outbreaks and health actions.

In the case of infectious diseases, which account nowadays more than $25 \%$ of annual deaths worldwide (Silva; Angerami, 2008), memory usually comes loaded with a negative charge due to the possibility of contagion. According to Donalísio (1999), people's relation with outbreaks is a material and a subjective matter at the same time since it deals with the transmitting agent, the infected individual and the work of disease control (material world) and representations and

Brazilian advertising market and responsible for verification of major newspapers and magazines in the country. values of the epidemiological phenomena in society (subjective world).

Le Goff (1985, p. 8) affirms that "the disease belongs not only to the superficial story of scientific and technological progress as well as to deep history of knowledge and practices related to social structures, institutions, representations, mentalities". For him, there is a story of suffering in outbreaks, particularly in past centuries, when the source of diseases was still a challenge for science.

In antiquity, the Greek Hippocrates, considered the father of medicine, used the word epidemeion in the sense of "to visit", referring to the provisional and temporal nature of an epidemic as opposed to endemeion (endemic) that translated the idea of "inhabit the place" designating the disease that is usually present in a particular social group. Despite being a collective phenomenon, the outbreak process has a history that individualizes it in time and space expressing itself in different ways. According to Foucault (2006, p. 26), the outbreak "requires a multiple look; single process, it must be described in what it has of singular, accidental and unforeseen".

The strong symbolic notion that outbreak has gained over the centuries is essential to see the sense effects about the diseases in journalistic texts. The feeling of the proximity of danger is present in the headlines and in the journalistic texts about outbreak diseases, indicating it is one of the health fears today (Ogrizek, Guillery and Mirabaud, 1996). In the press, death is usually one of the main figures in publishing news, based on news values that guide the press routine (Galtung and Ruge, 1965; Sodré, 2009).

These news criteria define whether a particular fact is interesting, meaningful and relevant enough to be turned into news by the journalistic field (Pereira Jr., 2000). Among the values, the novelty, the unpredictability and the temporal proximity are the three major since vehicles are used to spread new or olds news ones that have some new data, thus recovering their currency and bringing them to the present.

[...] is the media function to provide a continuous social present, fairly new to impress us and old enough to us to know and talk about it, as a way to assimilate and dominate it. From this perspective, we can think that news production and its interpretation in society is essential for this society to survive and live the "present" as a reference of the world, of nowadays today. (Gomes, Melo and Morais, 1999, p. 20, authors' emphasis)

Journalism presents to us uncompleted actions that have occurred in the past, others that may be happening at the moment and others that are still expected to occur in the near future. Following time perspective, we can also say that newsworthiness is conditioned primarily by the factor of time and that news have a certain life cycle (Morais, 1996). This cycle begins when the news starts circulating in press, becoming a present fact.

For a newspaper, the present has 24 hours, which corresponds to the day edition. I refer it because the 
enunciation ends at the time of its reading. I mean, the facts contribute to the preparation of determined action or attitude by individuals which is realized when they realize the act of reading of the journalistic text. From the informations related in that text the readers will be able to comment about the acts that have eventually occurred or are still occurring. The subjects commented will always be the present of the news and it assumes that it can be extended in its "life" until another present replaces it and takes its prominence in next 24 hours. (Morais, 1996, p. 164, author's emphasis)

The news cycle includes, therefore, since the moment that a fact is released for the first time until the interest about its information has faded. In other words, this is the period where the news have life for the reader. From the moment it reaches a saturation point, the cycle comes to an end and the press itself will try to replace it with another news that, according to the criteria of newsworthiness, attract public's attention. In this article, the fact that we are analyzing hard news brings up the issue of temporal proximity and life cycle of the news. In the case of dengue, news about increasing cases and deaths tend to bring the feeling of proximity of danger related to the present, one of news values.

Vieillard-Baron (2007, p. 315) believes that the feeling of insecurity has a close relation with the discourse and the risk of aggression maintained by the media as well as the society environment. This feeling is sustained by security progress and the man's will to control the world. "Consequently narrative explanation about risk is capital for people who want to control it".

Analyzing our corpus, we identify two major moments in which the occurrence of outbreaks promoted a greater production of news. The first occurred in early 2002 with the notification of explosive outbreak caused by the introduction of DENV-3, the third serotype of the virus in Brazil. From the total of 144 texts published in 2002, 119 were published in the first semester (82.6\% of total), mainly in February and March (94 texts). Compared with the reports of dengue fever, the news had a direct influence of the increase of its registrations. In that year, it was notified 116,148 cases, 111,729 in the first semester (95.7\% of recorded in 2002).

The second moment of large concentration of texts was observed in 2008, specifically in April with the register of the first death from dengue in the year (a child who was 8 years old). With the increasing of reports above average, the occurrence of death left the government in alert to the risk of a new outbreak in Pernambuco, leading him to proclaim publicly through the press several control measures to contain a possible spread of disease. Table 1 shows a comparison between cases of dengue and news published by semester in 2002, 2004, 2006 and 2008:

The context or risk of outbreaks leaded the Jornal do Commercio to publish news in a quantity far exceeding the normal periods. For us the increase in cases and deaths from dengue fever has a strong journalistic appeal, requiring the establishment of an almost continuous narrative of events because of the threat caused by the disease. Although outbreaks attract media attention, dengue is different than other diseases because it is a viral disease highly publicized in Brazilian press, especially from the 2000s, becoming a media phenomenon as it was AIDS in 1980s, having more value than others diseases (Ferraz, 2010).

Table 1. Comparison between cases and news about dengue fever by semester, 2002-2008

\begin{tabular}{lllllll}
\hline \multicolumn{3}{l}{ Notifications } & \multicolumn{5}{l}{ Journalist texts } \\
\hline Year & $\begin{array}{l}\boldsymbol{1}^{\boldsymbol{o}} \\
\text { semester }\end{array}$ & $\begin{array}{l}\mathbf{2}^{\boldsymbol{o}} \\
\text { semester }\end{array}$ & Total & $\begin{array}{l}\boldsymbol{1}^{\boldsymbol{o}} \\
\text { semester }\end{array}$ & $\begin{array}{l}\mathbf{2}^{\boldsymbol{o}} \\
\text { semester }\end{array}$ & Total \\
\hline 2002 & 111.729 & 4.419 & 116.148 & 119 & 25 & 144 \\
2004 & 4.676 & 1.650 & 6.326 & 5 & 6 & 11 \\
2006 & 12.934 & 5.695 & 18.629 & 6 & 24 & 30 \\
2008 & 38.079 & 2.934 & 41.013 & 94 & 12 & 106 \\
Total & 167.418 & 14.698 & 182.116 & 224 & 67 & 291 \\
\hline
\end{tabular}

Source: Site Jornal do Commercio (www.jc.com.br) / Health Departament of Pernambuco

Analyzing the headlines, it is possible to identify the senses created about dengue. For us, the notions of fear and evil are closely linked to the discursive production of infectious disease caused by a biological agent (in the case of dengue, a virus) that is transmitted by the mosquito Aedes aegypti. Understand this threat is important to understand media interest in the theme before the increasing of suspected cases and deaths. Table 2 shows some headlines that were published in 2002 and 2008:

Table 2. Journalistic statements during epidemic period - Jornal do Commercio, 2002 and 2008

\begin{tabular}{|c|c|}
\hline January, 23, 2002 & Confirmed $1^{\circ}$ case in Pernambuco \\
\hline February, 8, 2002 & Confirmed the first death by dengue in Pernambuco \\
\hline $\begin{array}{l}\text { February, 27, } \\
2002\end{array}$ & $\begin{array}{l}\text { Arrival of DENV-3 in Pernambuco difficults control of } \\
\text { dengue }\end{array}$ \\
\hline March, 1, 2002 & 843 people infected just in one day in Recife \\
\hline March, 7, 2002 & Recife has the largest outbreak of dengue \\
\hline April, 3, 2002 & Dengue progresses over 62 districts in Recife \\
\hline April, 12, 2002 & $\begin{array}{l}\text { Dengue has already reached } 163 \text { municipalities in the } \\
\text { state }\end{array}$ \\
\hline March, 26, 2008 & Dengue in falling in the state \\
\hline April, 10, 2008 & 8 -years-old child died of dengue hemorrhagic fever \\
\hline April, 04, 2008 & Dengue comes close and scares in cities of the country \\
\hline April, 30, 2008 & Danger of outbreak in Pernambuco \\
\hline May, 10, 2008 & Death rate is already higher than normal \\
\hline June, 12, 2008 & Increases to 13 number of deaths by dengue \\
\hline
\end{tabular}

Source: Site Jornal do Commercio (www.jc.com.br)

Coverage on dengue followed the tendency of the 
increasing of cases, reinforcing the focus given to the notification in the headlines. This is observed by the emphasis given to the verb "to confirm" - which means "to prove", "to demonstrate", "to show the truth" (Michaelis, 2009) - widely used as an enunciation strategy of the newspaper. The verbs "to infect" and "to increase" complement and reinforce this notifier sense, generating attention to the subject.

In addition to "to confirm", the verb "to reach" also appeared in titles, expressing the meaning of "to catch" and "to arrive"". Supported by the numbers of health, the newspaper mediates cases showing little by little, a framework of a possible uncontrolled situation. For us, the outbreak brings an underlying idea of invading the territory, as a foreigner, spreading the disease. According to Veyret (2007) the health risks amplify the concern about risks people are exposed to. In 2008, the feeling of fear appeared in the news in April, considered the most critical month for dengue fever in Pernambuco, when cases and deaths began to be reported.

\section{War Metaphors in Journalistic Discourse}

Governmental initiatives to control dengue had a privileged space in the newspaper, especially with the increased registration of cases and deaths. This kind of discourse is determined by actions that promise to eliminate the mosquito (inspections) and alert the public to the problem (public parades of protest, lectures and cultural events), besides new projects and announcements of government to ensure the control of the disease. In 291 texts produced by the Journal of Commerce in 2002, 2004, 2006 and 2008, efforts to fight dengue and announcements of new control measures totaled $27.5 \%$ of all news. The mosquito has become the villain of the story that it was necessary to fight.

In 2004 and 2006, public actions in allusion to D-Day Against Dengue also reinforced the discourse of war in relation to the disease. In Brazil, the inclusion of this date in public health calendar in the actions of dengue had began during the epidemic in $2002^{2}$. The purpose of this kind of event was to drive direct attention of society, so that it could be actively engaged in combat against the mosquitoes (Ministry of Health, 2002). In subsequent years, this campaign also has been absorbed by media calendar. It had acquired news values and had constituted one of those public moments "authorized" to talk about dengue.

Table 3 presents headlines reinforcing this combat:

\footnotetext{
${ }^{2}$ The first D-Day took place in Rio de Janeiro on March 9, 2002, when 745,000 servers locals and volunteers worked to stop the focus of mosquitoes. With other initiatives in place since February, mobilization involved about 14.6 million people, resulting to reverse $93.6 \%$ in the number of cases, which reduce from 90,776 in March to 5,722 in May. The success of this action had led the Ministry of Health to disseminate the experience in the same year for the states of São Paulo, Pernambuco, Goiás, Mato Grosso do Sul and Alagoas (Brazilian Ministry of Health, 2002).
}

Table 3. Banner headlines about Campaign Against Dengue - Jornal of Commercio, 2002-2008

$\begin{array}{ll}\begin{array}{l}\text { November, } \\ 19,2002\end{array} & \text { Campaign mobilizes against the dengue mosquito } \\ \text { November, } & \text { D-Day intensifies combat against dengue fever } \\ 24,2002 & \\ \text { November, } & \text { Campaign reinforces combat against dengue in Recife } \\ 20,2004 & \\ \text { November, } & \text { City hall of Recife intensifies actions against dengue fever } \\ 28,2004 & \text { Pernambuco antecipates mobilization in second worst year of } \\ \text { November, } & \text { outbreak } \\ 17,2006 & \text { National action mobilizes people against dengue } \\ \text { November, } & \\ 19,2006 & \text { New ofensive in the combat against dengue } \\ \text { November, } & \\ 2,2008 & \end{array}$

Source: Site Jornal of Commercio (www.jc.com.br)

In this type of speech, verbs commonly used are "to mobilize", "to combat", "to intensify" and "to anticipate". The first has a meaning of "to put into action", "to give movement" and, in a military sense, "to pass the state of peace for war". The second verb means "to fight", while the third, "to make intensive" and the fourth, "to perform ahead of time" (Michaelis, 2009). "Offensive", "mobilization", "action" and D-Day complement this sense.

The institution of the $D$-Day has military origins. The term was created by the United States Army during First World War to denote the command orders of a battle. It has been adopted since then. Currently, the term is used to mark the beginning of a combat operation. In terms of language, Sontag (2002) reminds us that military metaphors began to be used for the first time, ostensibly in the medical field, in the late nineteenth century, with the identification of bacteria and disease-causing agents. At this time, it referred to the "invasion" or "leakage" to describe the action of germs in the body. After that other terms appeared from awareness campaigns about syphilis that were held during World War I (1914-1918) and then the clarification about tuberculosis. In general, says Sontag (1989, p. 14), the metaphors "routinely present the disease as something that invades society, and attempts to reduce mortality caused by a certain disease are called fights and wars".

In Brazil, the use of war metaphors leads us to the first vaccination campaigns, the example of the strategy undertaken by scientist and director of Department of Health Oswaldo Cruz in the early twentieth century to contain a smallpox epidemic (Ujvari, 2003). The concepts of containment and surveillance, military-inspired, emerged after the First World War, being used by public health, that has adopted the view that the "enemy" to combat the health problems of the period. Later, these words were assimilated by the press in the construction of its discourse to treat illnesses, according to Gomes (2000, p. 190, emphasis added):

[...] in matters involving the development of drugs against diseases, studies are also treated as a war, with the use of terms such as challenge, strategy, attack and target driven. 
Because they belong to another context, such expressions act as resources needed in order to re-semanticizing what is stated.

Consider this historicity is essential to understand the relationships of current sense production in the "complex interplay of discourse" as Orlandi (2007) says. Even nowadays the notions of war and enemy are very present in public health discourse. Knowing that dengue can not be eliminated in the short term, Silva and Angerami (2008, p. 52) argue for a "guerrilla tactic" to "defeat the disease". The risk then becomes the notion that permeates the war against dengue, demanding the adoption of safe practices that reduce the imminent danger posed by the disease.

Among the four years analyzed, war discourse was more emphasized in 2008 . It was promoted by numerous actions by governments and civil society to the point that the newspaper inserted the words "combat", "war" and "action plan". In table 4, we indicate some examples of metaphors in the headlines:

Table 4. The militarization in the strategies for titration of the headlinesJornal of Commercio, 2008

\begin{tabular}{ll}
\hline Apr., 23 & $\begin{array}{l}\text { COMBAT AGAINST DENGUE: Fiscals attack 1868 focuses } \\
\text { in Recife }\end{array}$ \\
May, 2 & $\begin{array}{l}\text { FIGHT AGAINST DENGUE: Parade in Recife alert for } \\
\text { prevention }\end{array}$ \\
May, 19 & MEGAOPERATION: Recife unites against dengue \\
May, 20 & $\begin{array}{l}\text { COMBAT AGAINST DENGUE II: Hawkers are target of } \\
\text { action }\end{array}$ \\
May, 30 & $\begin{array}{l}\text { COMBAT AGAINST MOSQUITO: Pools grounded to } \\
\text { prevent dengue }\end{array}$ \\
May, 31 & $\begin{array}{l}\text { WAR AGAINST MOSQUITO: Confirmed the 11th death } \\
\text { from dengue }\end{array}$ \\
Wune, 1 & $\begin{array}{l}\text { WAR AGAINST MOSQUITO: Architecture is obstacle to } \\
\text { combat }\end{array}$ \\
July, 17 & $\begin{array}{l}\text { COMBAT AGAINST DENGUE: Action takes mosquito of } \\
\text { property }\end{array}$ \\
Oct., 24 & ACTION PLAN: State wants to streamline records of dengue
\end{tabular}

Source: Site Jornal of Commercio (www.jc.com.br)

All words highlighted have become significant in the title-giving strategies of the news. Fausto Neto (1999, p. 62) affirms that the use of operators in newspaper titles creates a sub-agenda on the topic in question within everyday agenda set by the vehicle of communication. "Through it, the newspaper announces a kind of 'rendezvous' with the reader". Thus, the combat against dengue occupied a privileged and visible space to the public of the Jornal do Commercio, giving different meanings to the headlines. This sub-agenda emphasized the reality experienced at that moment. More than "diversifying" the vocabulary of war, this new production revealed a kind of resurgence of discourses, further emphasizing the sense of combat. Some excerpts of news complement this idea of militarization to the extreme in news coverage:
(01)

"We will occupy every inch of the territory of the city", said Siqueira [Luciano Siqueira, vice-mayor of Recife], giving the dimension of the work and then emphasizing that the success in the fight against dengue depends on the partnership of all. (JC, 13/05/2008)

(02)

Visit, identify and destroy are the watchwords of the troop, composed of effective military and beginners of military service. Uniformed, the soldiers were yesterday on the streets of Várzea, Boa Viagem, Afogados, Alto José do Pinho, Mangabeira, Torreão, Campo Grande, Encruzilhada, Santo Antonio and Bairro do Recife. (JC, 20/05/2008)

The girl Lidiani Canuto da Silva, 11 years old, dressed up for the dengue mosquito and entered into the coffin. "We have to kill the bug him not to kill us", summed up the girl. (JC, 09/06/2008)

All strategies appeared to be valid, including to have a support of the army in government action to "occupation" of the territory of the city to ensure the effectiveness of the fight against the disease, as can be attested in example 01 , in the words of Luciano Siqueira vice-mayor of Recife at the time of the launch of one of the initiatives of combat. Already the watchwords of soldiers who participated in the campaign to eliminate outbreaks of the mosquito (Visit, identify and destroy) denote, in example 02 , the climate of the war against dengue that was being faced in the period.

The Aedes aegypti is considered by the mayor of Recife, João Paulo, a very strong opponent, able to cause great damage. His speech ends with the words of a war strategist ( "We won the battle but not the war"). In the narrative logic, these measures - promoted mostly by the government - had the function to improve an initial state of decontrol, with the elimination of the mosquito and the risk of the disease. The intention was to try to return to the previous situation of control, encouraging people to adopt a preventive behavior.

\section{Final Thoughts}

The discussion of dengue fever is fundamental for us to reflect also about the importance that infectious diseases have in social and media context. We believe that the meanings produced in the different discourses contributed to make the disease well known by Brazilian people due to the scope and penetration that the media has in contemporary society. The analysis of the discourses produced by Jornal do Commercio also makes us think about the power of the word "outbreak" in the discursive context, emphasizing the risk sometimes and other times serving as a background for disease combat.

War metaphors used so much by the journalistic field, in most of the time, have an ornamental function, according to Gomes (2000, p. 191-2). "That is, much more than trying to explain something, the journalist uses metaphors in search of a picturesque element to the characterization that he is referring". Thus metaphors demonstrate "a major concern of 
journalists with the involvement of the reader" adopting war expressions used for decades in the discourse of public health. In news about dengue, this dialogical discursive phenomenon reinforces the notion of an uncontrolled situation and searches, directly or indirectly, the adhesion of the society in the implementation of preventive measures.

In this paper, the analysis indicates the status acquired by the dengue virus from the explosive outbreak in 2002. Possibly no other infectious disease has had so much space in recent years on the news due to the cyclical occurrence of outbreaks and the risk of death from hemorrhagic form, which represents a growing threat. With the exception of influenza A(H1N1), which alarmed the planet with a pandemic declared in 2009 by WHO, dengue fever is held captive in the pages of Brazilian newspapers, making the experience of this disease more common for the population.

In general, the outbreak tends to be prioritized by unpredictability, novelty, social weight, geographic proximity, audience impact and outlook for the event, almost all the criteria that guide the newsworthiness of an event (Galtung and Ruge, 1965; Sodré, 2009). Moreover, the notion of epidemic discursively redeems the memory of ancient plagues in the constitution of the senses, bringing up ideas on matters such as fear, evil, death and risk. From the idea of proximity of the danger caused to each new epidemic, the press values the uncontrolled way of giving meaning to dengue. Perhaps, therefore, the use of metaphors of war - fairly common when speaking of health managers and media discourse in itself - is a form of co-responsibility in society, who is called to be part of the "army" in the "battle" against dengue.

Even though our research is focused on Discourse Analysis, we propose a critical evaluation about press coverage beyond Discourse Analysis and theories of journalism, indicating possible paths of reflection. More than emphasizing dengue fever on its stages of risk, we believe that the disease may also be subject of news in previous periods before the increase of cases in order to make people wake up to permanent prevention when it is still possible to eliminate the focus of mosquitoes, preventing the occurrence of diseases. In State of Pernambuco, the months from December to April are considered essential by experts to reduce the risk of dengue. Why not produce newspaper articles and launch educational campaigns during this period?

The government has a role in promoting health awareness, which can sensitize the media to talk about the importance of dengue in different periods of the year. Rather than fulfill the role of disseminating complete and transparent information, the government should encourage the adoption of healthy habits also in the press, stimulating a wider knowledge of journalists on the field of health.

Against the impossibility of eradicating the mosquito Aedes aegypti, the World Health Organization has defined since 1995 community and all sectors of society participation as one of the basic elements to prevent and control dengue, according to Guzman and Kouri (2006). When evaluating the treatment given to dengue by the media, we believe it is important to promote a discussion on the subject, rethinking communication strategies.

\section{Acknowledgement}

The authors are grateful to Olivier Georger French statistician for the support of this research and Natália Flores for her review. This article is derived from the dissertation of Ferraz (2010), funded by the Scholarship Assistance Program Reuni Education-UFPE (Pernambuco, Brazil).

\section{References}

[1] A.E.V. Pereira Jr, "Decidindo o que é notícia," Porto Alegre: Edipucrs. 2000.

[2] Brazilian Ministry of Health, "A sociedade contra a dengue," Serie B. Textos Básicos de Saúde. Brasília: Brazilian Ministry of Health, 2002.

[3] E.P. Orlandi, "As formas do silêncio: no movimento dos sentidos," 6. ed., Campinas: Editora da Unicamp, 2007.

[4] H. Vieillard-Baron, "Os riscos sociais," in Os riscos: o homem como agressor e vítima do meio ambiente, Y. Veyret, Org. São Paulo: Contexto, 2007, pp. 275-316.

[5] I. Gomes, C. Melo, W. Morais, "O movimento dos sentidos na mídia televisiva," Lumina, vol. 2, n. 3, pp. 17-28. Juiz de Fora-MG., July-December, 1999.

[6] I.M.A.M. Gomes, “A Divulgação Científica em Ciência Hoje: características discursivo-textuais," 2002，320p. Doctoral Thesis. Programa de Pós-graduação em Letras, Recife, 2000.

[7] J. Galtung. M.H. Ruge, "The structure of foreign news,". Journal of Peace Research, vol. 1, pp. 64-90. Noruega, 1965.

[8] J-J. Courtine, “Análise do discurso político: o discurso comunista endereçado aos cristãos," São Carlos: Ed. da UFSCar, 2009.

[9] J. Le Goff, "Uma história dramática," in As doenças têm história, J. Le Goff, 2nd. ed. Lisboa: Terramar, 1997.

[10] L.J. Silva, R.N. Angerami, "Viroses emergentes no Brasil," Rio de Janeiro: Fiocruz, 2008.

[11] L.M.R. Ferraz, "Epidemia e memória: narrativas jornalísticas na construção discursiva sobre a dengue," 2010, 250p. Master Dissertation. Programa de Pós-graduação em Comunicação, Recife, 2010.

[12] M. Cordeiro, E. Freese, H. Schatzmayr, R.M.R. Nogueira, "Vinte anos de evolução da dengue no estado de Pernambuco," Recife: Ed. da UFPE, 2008.

[13] M. Foucault, "O nascimento da clínica," 6 ed. Rio de Janeiro: Forense, 2006.

[14] M.G. Guzmán, G.G.G. Kourí, "El dengue y el dengue hemorrágico: prioridades de investigación, " Rev. Panamericana de Salud Pública, vol. 19, n. 3, pp. 204-215, Washington, 2006.

[15] M. Ogrizek, J.M. Guillery, C. Mirabaud, "Que sais-je? la communication médicale," Paris: Presses Universitaires de France, 1996. 
[16] M. Pêcheux, "Papel da memória," in Papel da memória, P. Achard, J. Davallon, J-L. Durand, M. Pêcheux, E.P. Orlandi, 2nd. ed. Campinas: Pontes, 2007, pp. 49-56.

[17] M.R. Donalísio, “O dengue no espaço habitado," São Paulo: Hucitec, 1999.

[18] M. Sodré, "A narração do fato: notas para uma teoria do acontecimento,” Petrópolis: Vozes, 2009.

[19] M.Z. Rouquayrol, N. Almeida Filho, "Epidemiologia e Saúde," 6 ed, Rio de Janeiro: MEDSI, 2003.

[20] Michaelis, “Dicionário Online Michaelis.” São Paulo: Melhoramentos, 2009.

[21] O. Ducrot, "O dizer e o dito," Campinas, SP: Pontes, 1987.

[22] P. Charaudeau, D. Maingueneau, "Dicionário de Análise do Discurso,” 2nd ed., São Paulo: Contexto, 2008.

[23] S.C. Uvjari, "A história e suas epidemias: a convivência do homem com os microorganismos," Rio de Janeiro: Senac, São Paulo: Senac, 2003.

[24] World Health Organization, "Dengue,", 2014.

[25] W. Morais, "El periodismo y el arte de contar historias - un estudio acerca de la construcción de la noticia científica". Doctor Thesis. Universidade Autonoma de Barcelona. 1996.

[26] Y. Veyret, "Introdução," in Os riscos sociais: o homem como agressor e vítima do meio ambiente, Y. Veyret, Org. São Paulo:
Contexto, 2007, pp. 11-21.

\section{Biography}

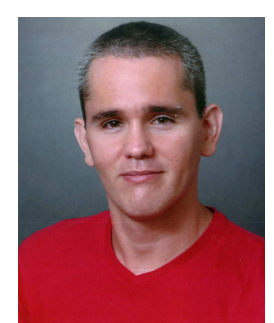

Luiz Marcelo Robalinho Ferraz is graduated in journalism from the Universidade Católica de Pernambuco (Unicap) and publicity from Universidade Federal de Pernambuco (UFPE). He is presently a $\mathrm{PhD}$ student in the "Health Information and Communication" Programme at the Fundação Oswaldo Cruz (Fiocruz) in Rio de Janeiro. Marcelo Robalinho worked as journalist at Jornal do Commercio (Recife) and press officer for the Health Department of Recife. His research area is communication and health, especially discourse analyses about diseases.



Isaltina Maria de Azevedo Mello Gomes has a degree in letters from the Philosophy Faculdade de Filosofia do Recife (Fafire) and social communication from Universidade Federal de Pernambuco (UFPE). She is $\mathrm{PhD}$ in linguistics from UFPE. Isaltina Gomes teaches presently journalism at the Department of Social Communication of UFPE. She studies language issues in the media, with special interest in science communication. 